\begin{tabular}{c} 
Contents lists available at BIOSFER \\
BIOSFER: JURNAL TADRIS BIOLOGI \\
p-ISSN: 2086-5945 (print), e-ISSN: 2580-4960 (online), DoI 10.24042/biosfer \\
http://ejournal.radenintan.ac.id/index.php/biosfer/index \\
\hline
\end{tabular}

\title{
Increasing Antioxidant Activity and Organoleptic Properties of Soursop Leaf Tea (Annona muricata Linn.) by Adding Cinnamon Powder (Cinnamomum burmanni)
}

\author{
Indarto $^{1 *}$, Salima Duwi Astuti², Mahmud Rudini ${ }^{3}$, Wisnu Pambudi ${ }^{4}$ \\ 1, 2, 3 Universitas Islam Negeri Raden Intan Lampung, Indonesia \\ ${ }^{4}$ Department of Rubber and Plastic Processing Technology, Politeknik ATK Yogyakarta, Indonesia
}

\begin{abstract}
ARTICLE INFO
Article History

Received : 16-10-2020

Accepted : 24-12-2020

Published : 31-12-2020

Keywords:

Antioxidant;

soursop leaf tea;

cinnamon;

soursop

*Correspondence email: indarto@radenintan.ac.id

ABSTRACT

Soursop leaf tea is a health drink that contains steroid compounds, terpenoids, flavonoids, kumari, tannins, and alkaloids. The flavonoids and tannins in soursop leaves act as antioxidants. Since it has an unpleasant aroma, cinnamon is added to add scent and flavor. This study aimed to determine the effect of cinnamon powder on the soursop leaf tea's antioxidant activity. This study employed the completely randomized design method (CRD) with two factors: the soursop leaves and cinnamon powder concentrations. This study consisted of four treatments, namely SP0 (100\% soursop leaves), SP1 (90\% soursop leaves and 10\% cinnamon powder), SP2 (80\% soursop leaves and 20\% cinnamon powder), and SP3 (70\% soursop leaves and $30 \%$ cinnamon powder) within three repetitions. The proximate test was focused on antioxidant activity analyzed by ANOVA at $\alpha=5 \%$. The organoleptic test covered the color, taste, aroma, and other overall preferences by qualitative descriptive tests. The results showed that the highest antioxidant $(29.19 \%)$ could be found in the SP3 sample $(70 \%$ soursop leaves and 30\% cinnamon powder), while the preferred organoleptic test was the SP2 sample.
\end{abstract}

Peningkatan Aktivitas Antioksidan dan Sifat Organoleptik Teh Daun Sirsak (Annona muricata Linn.) dengan Penambahan Bubuk Kayu Manis (Cinnamomun burmanni)

\footnotetext{
ABSTRAK: Teh daun sirsak adalah minuman kesehatan yang memiliki kandungan senyawa steroid, terpenoid, flavonoid, kumari, tanin, dan alkaloid. Senyawa flavonoid dan tanin pada daun sirsak berperan sebagai antioksidan. Teh daun sirsak memiliki aroma yang tidak enak sehingga ditambahkan kayu manis untuk menambah raoma dan cita rasa. Tujuan penelitian ini adalah untuk mengetahui pengaruh penambahan bubuk kayu manis terhadap aktivitas antioksidan teh daun sirsak. Metode penelitian ini adalah metode Rancangan Acak Lengkap (RAL) dengan menggunakan dua faktor yaitu konsentrasi daun sirsak dan konsentrasi bubuk kayu manis dengan 4 perlakuan yaitu SPO (100\% daun sirsak), SP1 (90\% daun sirsak dan 10\% bubuk kayu manis), SP2 (80\% daun sirsak dan 20\% bubuk kayu manis) dan SP3 (70\% daun sirsak dan 30\% bubuk kayu manis) dengan 3
} 
kali pengulangan. Uji proksimat meliputi aktivitas antioksidan yang dianalisis dengan uji annova pada $\alpha=5 \%$. Uji organoleptik meliputi warna, rasa, aroma serta kesukaan secara keseluruhan dilakukan dengan uji deskriptif kualitatif. Hasil penelitian menunjukkan antioksidan tertinggi pada perlakuan SP3 (70\% daun sirsak dan 30\% bubuk kayu manis) sebesar 29,19\% sedangkan uji organoleptik perlakuan SP2 lebih disukai.

\section{INTRODUCTION}

Soursop leaf tea has antioxidant activity (Irawan \& Mahmudiono, 2018; Lubis, 2018; Masitha \& Febriansah, 2019) that can ward off free radicals and prevent degenerative diseases and cancer. Besides antioxidant activity, soursop leaf tea also has been tested for its antibacterial activity (Muizuddin \& Zubaidah, 2015; Yanti et al., 2020), antihypertensive (Dinanti, 2019; Sangging \& Sari, 2017), macrophage cell phagocytosis, and lymphocyte cell proliferation activity (Ulfah et al., 2018; Vitri Sari Nur Cahyani, 2017), cytotoxic activity (Yulia \& Rosi, 2016), lowering uric acid (Mutiara \& Wildan, 2019; Sugeng \& Prayogi, 2014), lowering cholesterol (Mutiara \& Wildan, 2019), antiinflammatory (Oliveira et al., 2017), and antidepressants (Bikomo et al., 2017).

Cinnamon also has high antioxidant activity (Brodowska et al., 2016; Ervina et al., 2016; Lalami et al., 2019) and has a distinctive aroma to enrich antioxidants. It is also used to add flavor and aroma to food and beverage products such as chocolate (Muhammad et al., 2018, 2019), yogurt (Helal \& Tagliazucchi, 2018), secang drinks (Hastuti \& Rustanti, 2014; Rahmiati, 2020), the cocoa leaf tea (Sadimantara et al., 2019), and avocado juice (Apriliani, 2020).

Soursop leaf tea can even be found on the market; however, the taste and aroma are not commonly liked (Irawan \& Mahmudiono, 2018; Muizuddin \& Zubaidah, 2015), additional ingredients are needed so that the consumers can like it. This study described cinnamon powder's addition to soursop leaf tea to increase antioxidant activity, taste, and aroma.

\section{METHOD}

\section{Materials}

The materials used in this study were soursop leaves, cinnamon, tea bags, aluminum foil, mineral water, methanol, and Diphenylpicryl-hydrazine (DPPH).

\section{Method}

This study employed a completely randomized design (CRD) with four treatments and three repetitions. The parameters observed were antioxidant activity, and organoleptic properties consisted of aroma, color, and taste. The ratio of the soursop leaves and cinnamon powder were SP0 (1: 0), SP1 (9: 1), SP2 (8: 2), and SP3 (7:3).

\section{Sample Preparation}

The picked soursop leaves were the fifth up to the tenth leaves. The leaves were then sorted and washed using clean running water and then drained. The drained leaves were then cut using scissors into smaller pieces. Furthermore, the soursop leaves were dried through the wind-drying technique and then mashed using a blender. On the other hand, the cinnamon was washed, drained, dried, and mashed using a blender.

\section{The Soursop Leaf Tea Making Process}

Two grams of the soursop leaf tea were inserted into tea bags with a composition ratio according to SP0, SP1, SP2, and SP3. The tea was then brewed with 100 $\mathrm{mL}$ of water at $70^{\circ} \mathrm{C}$ for 5 minutes and then cooled down. 
Antioxidant Activity Test

\section{Preparing the DPPH Solution $\mathbf{0 . 0 0 4 \%}$ (0.004 gram / $100 \mathrm{~mL}$ )}

Four milligrams of DPPH were dissolved in $100 \mathrm{~mL}$ methanol. The solution was shaken until it became homogeneous. The maximum wavelength used for DPPH was $517 \mathrm{~nm}$.

\section{Sample Measurement}

A total of $2 \mathrm{~mL}$ of soursop leaf tea was put into a $5 \mathrm{~mL}$ volumetric flask wrapped in aluminum foil. Furthermore, $2 \mathrm{~mL}$ of DPPH solution and methanol were added. The solution was homogenized and incubated at room temperature for 30 minutes. The absorbance of the sample was measured using a UV-Vis spectrophotometer at a wavelength of $517 \mathrm{~nm}$. Each treatment was repeated three times. The percentage of inhibition had been calculated using the following equation:

$$
\% \text { antioxidant activity }=\frac{\text { absorbance blank-absorbance of sample }}{\text { absorbance blank }} \times 100 \%
$$

\section{Organoleptic Test}

Twenty-five panelists performed the organoleptic test. The soursop leaf tea's organoleptic assessment parameters were the aroma, taste, color, and acceptance or preference. The panelists were asked to observe the taste, color, and smell of the soursop leaf tea from each treatment using their five senses. They assessed the product using a predetermined assessment score. The questionnaire sheet contained nine scoring criteria, namely extremely like (9), strongly like (8), like (7), somewhat like (6), neutral (5), somewhat dislike (4), dislike (3), strongly dislike (2), and extremely dislike (1).

\section{Data Analysis}

The data were analyzed qualitatively and quantitatively. The qualitative analysis was performed to explain the results of the organoleptic test. Meanwhile, the quantitative analysis was performed to describe the data of the antioxidant activity test. Furthermore, the data were then analyzed using the Analysis of Variance (ANOVA) formula assisted by SPSS 16.0. The test was then continued with the Duncan Multiple Range Test (DMRT) at a significant level of $5 \%$.

\section{RESULTS AND DISCUSSION}

\section{Antioxidant Activity}

The testing was performed using the DPPH (1,1-diphenyl-2-picrylhydrazyl method) measured by a UV-Vis Cary 50 spectrophotometer at a maximum wavelength of $517 \mathrm{~nm}$. The $517 \mathrm{~nm}$ wavelengths stabilize free radicals to be reduced by antioxidant compounds (Untsa Uzlifah, n.d.). The antioxidant activity of the varied concentration of soursop leaf tea with cinnamon powder can be seen in Table 1 . The results of the antioxidant activity tests indicated an increase in antioxidant activity. Soursop leaf tea (SP0) has an antioxidant activity of $10.05 \%$; with $10 \%$ cinnamon powder (SP1), the antioxidant content increased to $15.09 \%$. The same results were also shown by the SP2 and SP3 treatments. The more cinnamon levels were added, the higher the antioxidant activity. Cinnamon contains many compounds, including cinnamaldehyde, cinnamyl acetate, and cinnamyl alcohol. The Cinnamaldehyde compound belongs to the phenylpropanoid group that plays a vital role in antioxidant activity (Al Mahbub \& Swasono, 2017). Also, it causes the antioxidant activity to increase. 
Biosfer, 10 (1), 2020 101-110

Indarto Indarto, Salima Duwi Astuti, Mahmud Rudini, Wisnu Pambudi

Table 1. The Antioxidant Activity of Soursop Leaf Tea with the Addition of Cinnamon Powder

\begin{tabular}{ccccc}
\hline Samples & Repetition & Abs & $\begin{array}{c}\text { Antioxidant } \\
\text { Activity (\%) }\end{array}$ & $\begin{array}{c}\text { Antioxidant Activity } \\
\text { Duncan Test (\%) }\end{array}$ \\
\hline \multirow{2}{*}{ SP0 } & 1 & 0.3621 & 9.20 & $10.05^{\mathrm{a}} \pm 0,82$ \\
& 2 & 0.3584 & 10.13 & \\
SP1 & 3 & 0.3556 & 10.83 & $15.09^{\mathrm{b}} \pm 1,31$ \\
& 1 & 0.3420 & 14.24 & \\
SP2 & 2 & 0.3413 & 14.42 & $17.21^{\mathrm{c}} \pm 0,58$ \\
& 3 & 0.3326 & 16.60 & \\
SP3 & 1 & 0.3325 & 16.62 & $29.19^{\mathrm{d}} \pm 0,39$ \\
& 3 & 0.3279 & 17.78 & \\
\hline
\end{tabular}

The one-way ANOVA test result showed that $\mathrm{p}<0.05$ indicated an effect of cinnamon powder's addition on soursop leaf tea's antioxidant activity. The results of the Duncan test showed a significant difference between concentrations. The results proved that the addition of cinnamon powder to soursop leaf tea increased the antioxidant activity. The addition of cinnamon also increases snake fruit peel herbal tea (putri puncak anjani et al., 2015). Besides having antioxidant activity, cinnamon also has potential for antibacterial activity (Qomar et al., 2018; Reppi et al., 2016), anti-fungal (Nuryanti et al., 2015), and lowering blood glucose levels (Kondoy et al., 2013). Soursop leaves contain compounds such as flavonoids, tannins, coumarin, terpenoids, steroids, and alkaloids (Adri \& Hersoelistyorini, 2013). The flavonoid in soursop leaves is a class of antioxidant compounds. There is a good correlation between total flavonoids and antioxidant activity (Perwiratami, 2019). The antioxidant activity is influenced by the level of total flavonoids extracted from soursop leaves; the higher the total flavonoids, the stronger the antioxidant activity (Yuliantari et al., 2017).

\section{Organoleptic test}

The organoleptic test involved 25 untrained panelists. Aroma, color, and taste were the parameters of soursop leaf tea's organoleptic properties with cinnamon powder. The organoleptic test (Figure 1) obtained varying results, ranging from the aroma, color, and taste. The varying results were caused by cinnamon powder and soursop leaf tea's different concentrations, which affected each treatment's aroma, color, and taste. 


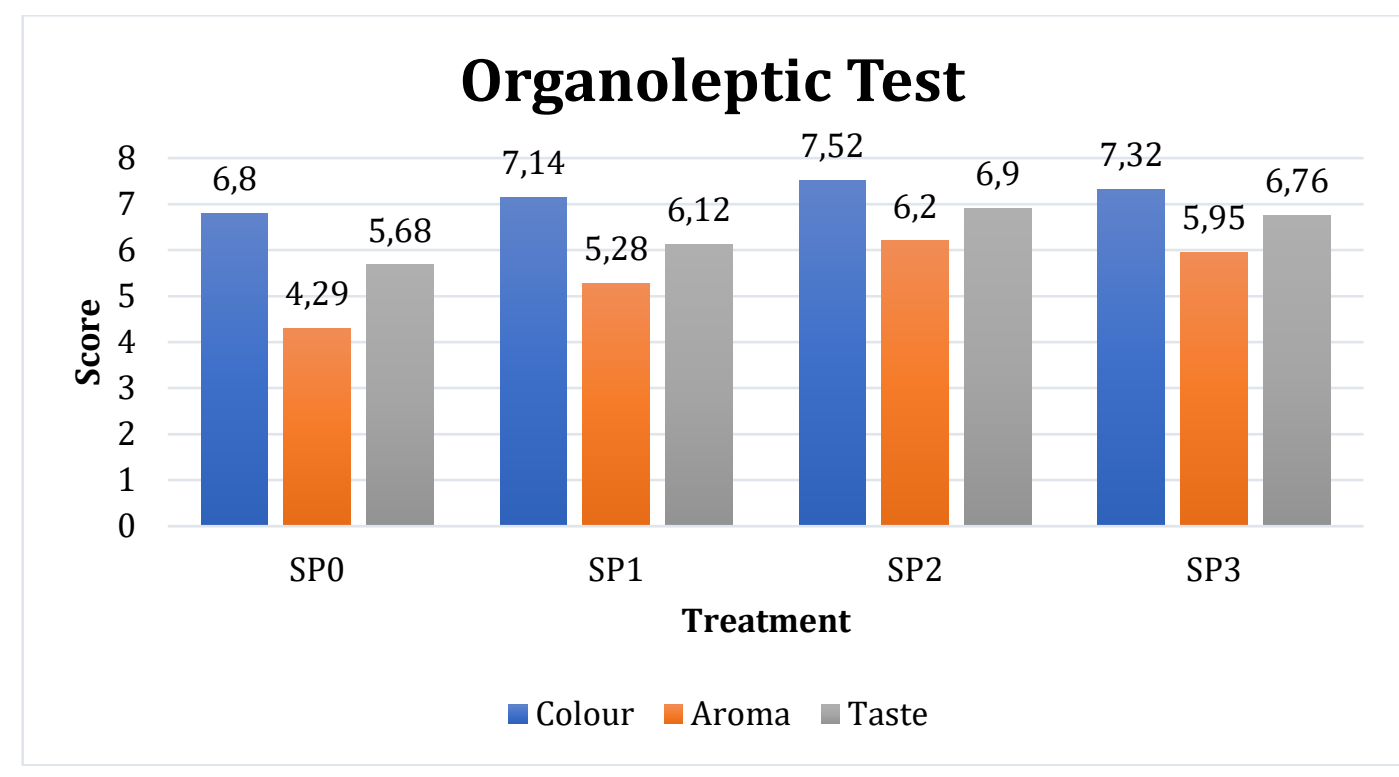

Figure 1. The Soursop Leaf Tea Organoleptic Test Results

\section{Color}

Based on the organoleptic test results, among the four treatments, the most preferred color was the SP2 sample with a score of 7.52, and the least preferred sample was the SP0 sample. The results showed that the addition of cinnamon powder affected the color of the soursop leaf tea.

The higher concentration of cinnamon powder added to the tea, the darker its color (browner). The main component contained in cinnamon is cinnamaldehyde. Besides acting as an antioxidant, it also acts as a color and aroma giver. The more cinnamon content, the more cinnamaldehyde dissolves into the soursop leaf tea, darkening its color. The result was in line with the research conducted by Andriana Murdi Hastuti, who stated that the higher the amount of cinnamon in functional drinks, the darker the functional drinks would be because the cinnamaldehyde in cinnamon, which is yellowish, dissolves even more. Thus, high cinnamon concentration added, the color will be getting darker (Hastuti \& Rustanti, 2014).

\section{Aroma}

The tea's aroma is produced by essential oil compounds with volatile properties and is easy to reduce. If the compounds are exposed to heat during brewing, a distinctive tea aroma will be produced (Adri \& Hersoelistyorini, 2013).

Based on the organoleptic test results (Figure 1), the preferred aroma was the SP2 sample with a score of 6.2 , while the least preferred aroma was the SP0 sample with a score of 4.29. The results indicated that the consumers disliked the aroma if the primary composition is only soursop leaf tea. The cinnamon powder adds the aroma of the tea and makes it more delicious.

The aroma is smell and taste is subjective and difficult to measure. Everyone has different levels of sensitivity and preferences. The molecular gases can stimulate sensitive odors in the nasal cavity. The aroma will be felt when the gas has passed through the ends of the olfactory.

The addition of cinnamon powder greatly affected the aroma produced by the soursop leaf tea. Soursop leaves have a typical unpleasant smell. On the other hand, cinnamon has a distinctive aroma produced by cinnamaldehyde and eugenol. Besides acting as an antioxidant, cinnamaldehyde also gives flavor and color to beverages (Hastuti \& Rustanti, 2014). Cinnamon contains a robust aroma to improve the unpleasant aroma of soursop leaves to be more fragrant. Cinnamon has an aromatic 
smell characteristic produced by the essential oil present in all cinnamon plants.

\section{Taste}

Organoleptic test results for the taste of soursop leaf tea can be seen in Figure 1. The highest taste score was 6.9 for the SP2 sample, and the lowest score was 5.68 for the SP0 sample. The result was in line with the results of the organoleptic test for color and aroma. The SP2 sample $(20 \%$ addition of cinnamon) was the most preferred sample of the four treatments. The cinnamon powder adds flavor to the tea. Cinnamon has a total sugar content of approximately $1.25 \%$ (Hastuti \& Rustanti, 2014), thus improving the soursop leaf tea's taste.

The compounds found in the taste of food or drinks are chemical compounds that can affect the body's senses, such as the taste buds (tongue). The tongue can recognize taste because it has taste buds. The sensitive microscopic hairs or microvilli found in the taste buds consist of sensory nerves that convey messages to the brain regarding various tastes, such as sweet, salty, sour, and bitter.

The addition of cinnamon powder to soursop leaf tea increases antioxidant activity that is good for health and adds color, aroma, and taste to be more accepted by consumers.

\section{CONCLUSIONS AND SUGGESTIONS}

Cinnamon powder's addition to soursop leaf tea can increase antioxidant levels from $10.05 \%$ (SP0) to $29.19 \%$ (SP3). It also adds color, aroma, and taste to soursop leaf tea to become tastier. However, it is necessary to test the nutritional content of soursop leaf tea products.

\section{REFERENCES}

Adri, D., \& Hersoelistyorini, W. (2013). Aktivitas antioksidan dan sifat organoleptik teh daun sirsak

$$
\begin{array}{lrr}
\text { (Annona } & \text { muricata } & \text { Linn.) } \\
\text { berdasarkan } & \text { variasi } & \text { lama } \\
\text { pengeringan. Jurnal Pangan } & \text { Dan Gizi, } \\
\text { 4(1). } &
\end{array}
$$

Al Mahbub, A. S., \& Swasono, M. A. H. (2017). Pengaruh Proporsi Kayu Secang (Caesalpinia Sappan L.) dan Kayu Manis (Cinnamomum Burmanii Bl) Terhadap Aktivitas Antioksidan "Wedang Semanis." Teknologi Pangan: Media Informasi Dan Komunikasi Ilmiah Teknologi Pertanian, 8(2), 107-114.

Apriliani, R. (2020). Pengaruh Penambahan Kayu Manis (Cinnamomum Verum) Terhadap Karakteristik Organoleptik Dan Antioksidan Minuman Sari Buah Alpukat (Perseaamericana Mill). Jurnal Sains Dan Teknologi Pangan, $4(6)$.

Bikomo, E. O., Magbagbeola, O. A., \& Ebuehi, O. A. (2017). Antidepressant activity of ethanol leaf extract of Annona muricata L., in Sprague-Dawley rats.

Brodowska, K. M., Brodowska, A. J., Śmigielski, K., \& \LodygaChruścińska, E. (2016). Antioxidant profile of essential oils and extracts of cinnamon bark (Cinnamomum cassia). European Journal of Biological Research, 6(4), 310-316.

Dinanti, D. (2019). Pengaruh Pemberian Rebusan Teh Daun Sirsak Terhadap Penurunan Hipertensi Pada Ibu Menopause di Posyandu Lansia Tlekung Kecamatan Junrejo Kota Batu [PhD Thesis]. Poltekkes RS dr. Soepraoen.

Ervina, M., Nawu, Y. E., \& Esar, S. Y. (2016). Comparison of in vitro antioxidant activity of infusion, extract and fractions of Indonesian Cinnamon (Cinnamomum burmannii) bark. 
International Food Research Journal, 23(3), 1346.

Hastuti, A. M., \& Rustanti, N. (2014). Pengaruh penambahan kayu manis terhadap aktivitas antioksidan dan kadar gula total minuman fungsional secang dan daun stevia sebagai alternatif minuman bagi penderita diabetes melitus tipe 2 [PhD Thesis]. Diponegoro University.

Helal, A., \& Tagliazucchi, D. (2018). Impact of in-vitro gastro-pancreatic digestion on polyphenols and cinnamaldehyde bioaccessibility and antioxidant activity in stirred cinnamon-fortified yogurt. $L W T, 89,164-170$.

Irawan, R. J., \& Mahmudiono, T. (2018). The antioxidant activity and organoleptic properties of soursoup leaf tea (Annona Muricata L.) and moringa leaf (Moringa Oliefera L.) in combination with guava leaf (Psidium guajava). Indian Journal of Public Health Research \& Development, 9(11), 1703-1707.

Kondoy, S., Wullur, A., \& Bodhi, W. (2013). Potensi ekstrak etanol daun kayu manis (Cinnamomum burmanii) terhadap penurunan kadar glukosa darah dari tikus putih jantan (rattus norvegicus) yang di induksi Sukrosa. Pharmacon, 2(3).

Lalami, A. E. O., Moukhafi, K., Bouslamti, R., \& Lairini, S. (2019). Evaluation of antibacterial and antioxidant effects of cinnamon and clove essential oils from Madagascar. Materials Today: Proceedings, 13, 762-770.

Lubis, L. A. (2018). Aktivitas Antioksidan Pada Teh Daun Sirsak (Annona muricata L.) Berdasarkan Variasi Lama Pengeringan Dengan Metode
$\mathrm{DPPH} \quad(1, \quad 1-$ diphenyl-2-
picrylhydrazyl).

Masitha, F. S., \& Febriansah, R. (2019). Antioxidant Activity from the Combination of Ethanolic Extract of Tea Leaves (Camellia sinensis) and Soursop Leaves (Annona muricata l.) and Optimation of the Effervescent Granule Production. Mutiara Medika: Jurnal Kedokteran Dan Kesehatan, 19(2), 56-63.

Muhammad, D. R. A., Gonzalez, C. G., Doost, A. S., Van de Walle, D., Van der Meeren, P., \& Dewettinck, K. (2019). Improvement of antioxidant activity and physical stability of chocolate beverage using colloidal cinnamon nanoparticles. Food and Bioprocess Technology, 12(6), 976-989.

Muhammad, D. R. A., Saputro, A. D., Rottiers, H., Van de Walle, D., \& Dewettinck, K. (2018). Physicochemical properties and antioxidant activities of chocolates enriched with engineered cinnamon nanoparticles. European Food Research and Technology, 244(7), 1185-1202.

Muizuddin, M., \& Zubaidah, E. (2015). Studi Aktivitas Antibakteri Kefir Teh Daun Sirsak (Annona muricata linn.) dari Berbagai Merk Teh Daun Sirsak Dipasaran [In Press September 2015]. Jurnal Pangan Dan Agroindustri, 3(4).

Mutiara, E. V., \& Wildan, A. (2019). Uji Aktivitas Minuman Teh Daun Sirsak (Annona Muricata Linn.) Sebagai Penurun Asam Urat Dan Kolesterol Secara In Vitro. Media Farmasi Indonesia, 14(1), 1427-1434.

Nuryanti, S., Jura, M. R., \& Nursucianti, N. (2015). Uji Aktivitas Anti Jamur Ekstrak Kayu Manis (Cinnamomum 
burmanii Blume) Terhadap Jamur Candida Albicans. Jurnal Akademika Kimia, 4(3), 123-128.

Oliveira, A. P., Sá, I., Pereira, D. M., Gonçalves, R. F., Andrade, P. B., \& Valentão, P. (2017). Exploratory Studies on the in Vitro Anti-inflammatory Potential of Two Herbal Teas (Annona muricata L. and Jasminum grandiflorum L.), and Relation with Their Phenolic Composition. Chemistry \& Biodiversity, 14(6), e1700002.

Perwiratami, C. (2019). Korelasi fenolat total dan flavonoid total dengan antioksidan dari beberapa sediaan ekstrak buah tanjung (Mimusops elengi). Chemistry Progress, 7(1).

putri puncak anjani, shelly andrianty, \& tri dewanti widyaningsih. (2015). Pengaruh penambahan pandan wangi dan kayu manis pada teh herbal kulit salak bagi penderita diabetes. Jurnal Pangan Dan Agroindustri, 3(1), 7.

Qomar, M. S., Budiyanto, M. A. K., Sukarsono, S., Wahyuni, S., \& Husamah, H. (2018). Efektivitas berbagai konsentrasi ekstrak daun kayu manis (Cinnamomum burmannii [Ness.] BI) terhadap diameter zona hambat pertumbuhan bakteri Staphylococcus epidermidis. Jurnal Biota, 4(1), 1218.

Rahmiati, R. (2020). Pengaruh Penambahan Kayu Manis (Cinnamomum bermanni) Terhadap Antioksidan Minuman Serbuk Instan Kayu Secang (Caesalpiniasappan L.) [PhD Thesis]. Universitas Teknologi Sumbawa.

Reppi, N. B., Mambo, C., \& Wuisan, J. (2016). Uji efek antibakteri ekstrak kulit kayu manis (Cinnamomum burmannii) terhadap Escherichia coli dan
Streptococcus pyogenes. EBiomedik, 4(1).

Sadimantara, M. S., Asranudin, A., Sadimantara, F. N., Suwarjoyowirayatno, S., \& Rhenyslawaty, R. (2019). Karakteristik Organoleptik, Sifat Kimia Dan Aktivitas Antioksidan Teh Formulasi Daun Kakao Dan Kayu Manis. Jurnal Sains Dan Teknologi Pangan, 3(5).

Sangging, P. R. A., \& Sari, M. R. N. (2017). Efektivitas Teh Daun Sirsak (Annona muricata Linn) Terhadap Hipertensi. Jurnal Majority, 6(2), 50-55.

Sugeng, S., \& Prayogi, A. S. (2014). Efektivitas Pemberian Terapi Teh Daun Sirsak Terhadap Kadar Asam Urat Pada Penderita Gout Arthritis Di Puskesmas Gamping Ii Sleman Yogyakarta. Jurnal Kesehatan Karya Husada, 2(1), 25-34.

Ulfah, M., Cahyani, V. S. N., \& Kinasih, I. (2018). Pengaruh Pemberian Seduhan teh Daun Sirsak (Annona muricata L.) Terhadap Aktivitas Fagositosis sel Makrofag dan Proliferasi sel Limfosit Mencit Galur Balb/C Yang Diinduksi Vaksin Hepatitis B. Majalah Ilmiah Momentum, 13(2).

Untsa Uzlifah. (n.d.). Aktivitas antioksidan sirup kombinasi daun sirsak (annona muricata linn.) dan kulit buah naga (hylocereus costaricensis) dengan variasi lama perebusan [Skripsi]. Universitas Muhammadiyah Surakarta.

Vitri Sari Nur Cahyani, V. (2017). Pengaruh Pemberian Seduhan Teh Daun Sirsak (Annona Muricata L.) Terhadap Aktivitas Fagositosis Sel Makrofag Mencit Galur Balb/C Yang Diinduksi 
Vaksin Hepatitis $B$ [PhD Thesis]. Universitas Wahid Hasyim Semarang.

Yanti, N. A., Ambardini, S., Ardiansyah, A., Marlina, W. O. L., \& Cahyanti, K. D. (2020). Aktivitas Antibakteri Kombucha Daun Sirsak (Annona muricata L.) Dengan Konsentrasi Gula Berbeda. Berkala Sainstek, 8(2), 35-40.

Yulia, M., \& Rosi, D. H. (2016). Uji Aktivitas Sitotoksik Ekstrak Etanol dari Variasi Teh Daun Sirsak (Annona muricata Linn) Terhadap Larva Udang (Artemia salina Leach). Scientia: Jurnal Farmasi Dan Kesehatan, 6(1), 13-17.

Yuliantari, N. W. A., Widarta, I. W. R., \& Permana, I. (2017). Pengaruh suhu dan waktu ekstraksi terhadap kandungan flavonoid dan aktivitas antioksidan daun sirsak (Annona muricata L.) menggunakan ultrasonik. Media Ilmiah Teknologi Pangan, 4(1), 35-42. 
Biosfer, 10 (1), 2020 101-110

Indarto Indarto, Salima Duwi Astuti, Mahmud Rudini, Wisnu Pambudi 